\title{
The Protection of Woman's Right to Dower in Islamic Law
}

\author{
Hafiz Muhammad Siddique \\ Faculty of Shariah \& Law \\ International Islamic University \\ Muhammad Atif Aslam Rao \\ Department of Islamic Learning \\ University of Karachi
}

\begin{abstract}
Dower is one of the fundamental rights of woman provided by Islam. This right provides woman economic and financial stability at the beginning of her married life. This study evaluates the concept of dower in Islamic perspective by explicating its significance and legitimacy. It also denotes the importance of dower in marriage contract. The quantum of dower may be fixed or decided according to the families, they are living with, if not mentioned in the contract of marriage. Present study also argues that Islam has not specified the quantum of Dower however the jurists believe that there are different specifications in terms of maximum and minimum quantum. This research aims to demonstrate the reasons of why Islam has promoted dower as a right of woman that invalidates the marriage contract if unpaid. However, Islam strictly prohibits the ostentatious manifestations of Pakistani societies that could trouble the individuals and society holistically. This paper concludes that how Islam has protected woman by providing her right to dower.
\end{abstract}

Keywords: Woman, Right, Dower, Islam, Family Law.

$$
\begin{aligned}
& \text { تلخيص }
\end{aligned}
$$

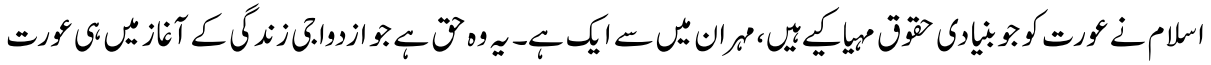

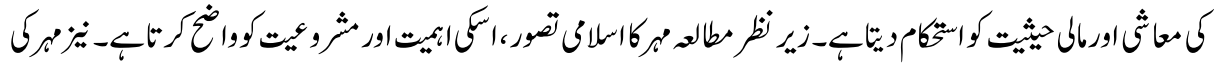

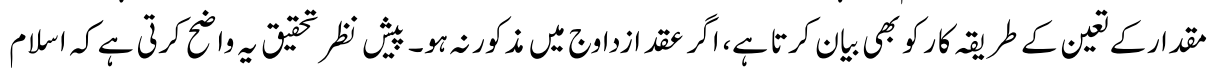

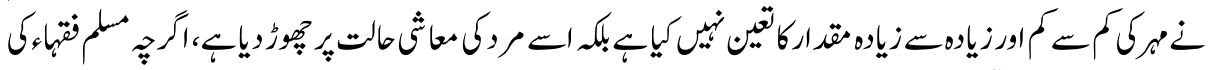

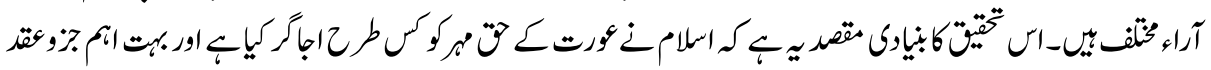

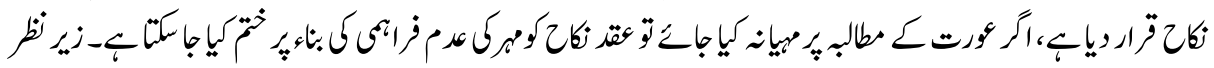

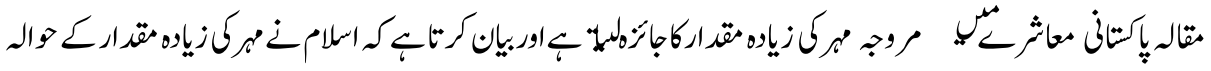

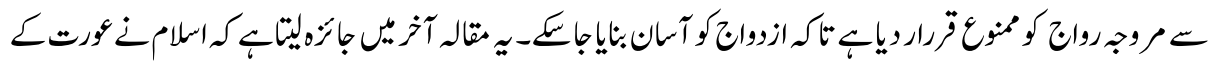

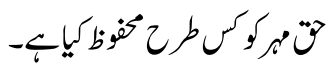

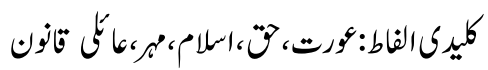




\section{Introduction}

Dower is one of the main ingredients and elements for a marriage contract and to be paid by the husband to his wife. The quantum of dower may be mutually fixed or adjusted by the spouses but it has to be according to the financial capability of a husband. Mahr is a consideration for wife's sole and it could be used by her exclusively for her benefits. In Islamic Law, Dower is considered as a reward for a woman giving herself to the husband. It is not a consideration for sale of a girl to a husband. But it is a token of the truthfulness and earnestness of the affection of the man. It is a financial right of a woman and belongs to her and none else. As there was a practice before Islam that dower was the property of her parents and in some countries heavy dowry is given by the parents of a girl in a marriage contract but it becomes the property of the husband after marriage. Islam is the only religion that provides an absolute financial right in shape of dower and a wife can demand from her husband. She is authorized to utilize the amount of dower according to his desires and wishes.

Mahr is an Arabic term used for dower and it is one of the woman's rights imposed by Shari 'ah on husband towards his wife. Lexically the term dower is from an Arabic root word Mahr, which means "a thing that is given to a woman in consideration of marriage contract or anything that is made or presented to a woman for marriage tie" (Mustafa, n.d, p. 889). The legal and technical definition of the term dower according to Hanafi Jurists as: "The property which is incumbent on a husband either by reason of its being named in the contract of marriage, or by virtue of the contract itself, as opposed to the usufruct of the wife's person" (Baillie, n.d). It means that the husband has to give dower money or any property to his wife even specified in nikahnama or not. However, this definition and others (Siddiqi, 1988, p. 79) introduce the importance of dower in the marriage contract. Through this right Islam honors wife that indicates true desire of the husband to become his partner.

Justice Dr. Tanzil-ur-Rahman defines that "Dower is a financial gain which the wife is entitled to receive from her husband by virtue of the marriage contract itself whether named or not in the contract of marriage" (Tanzil-ur-Rahman, 1978, p. 218). Justice Mahmood defines Dower as "Dower, under the Mahammadan Law, is a sum of money or other property promised by the husband to be paid or delivered to the wife in consideration of the marriage, and even where no dower is excessively fixed or mentioned at the marriage ceremony, the law confers the right of dower upon the wife" (Abdul Kadir vs. Salima, 1886, pp. 149, 157).

Abu Al-Nur explains that the dower is a thing husband offers to a wife in order to accept him as a partner as he states that "the dower honors the woman in different ways, provided that the woman is not only for enjoyment and that marriage is not looked upon 
as sex" (Ahmadi, 1992, p. 407). Imam Muhammad 'Abduhu argues that one should look at the dower as something superior to what Muslim jurists had referred to. The dower, or sadaq, is not an exchange of or the price for the body (ibid).

Thus, Mahr is a first financial right of a woman by virtue of the marriage contract which she is entitled to obtain from her husband either fixed or not; if specified or fixed then fixed amount otherwise Mahr Mithl (equal dower to the female members of her family) as denoted by the Muslim jurists.

In Islamic Law a marriage contract is to be concluded with free will of the parties without duress. The Holy Qur'an and Sunnah of the Holy Prophet (PBUH) explicitly prohibit such marriages arranged without consent and permission of contracting parties. Islamic Law has sanctioned several types of marriages due to the social, financial and physical situation of the person in certain circumstances. Muslim jurists discussed several kinds of marriage contract on the basis of social and financial position of a man. Sometimes, it becomes obligatory, sometimes, prohibited, sometimes, disapproved and if the person is in normal situation then nikah is recommended. Islam grants to marriage an evident status in constructing the family system. Because marriage holds an important position in family institution that encompasses both 'ibadat and mu' amalat. It is considered as a civil contract due to the general resemblance with other types of contracts in which free will of the parties is mandatory for making it effective, however, it is like worship due to the undetermined relationship of the parties, and so, it is considered a sacrosanct contract in Muslim Family Law. Muslim Jurists have denoted several elements of marriage contract but cure essentials are:
a. Legal capacity of contracting parties
b. Offer
c. Acceptance
d. Payment of Dower
e. Two Witnesses

It is endorsed that dower is measured as an essential element of the marriage contract, payable by the husband to his wife. If the dower amount is not paid at the time of marriage contract then it is to be paid when demanded by the wife and if the amount is not specified than mahr mithl is to be considered. Thus, a husband is legally obliged to pay the dower amount for accomplishing the marriage contract and it is a right of a woman, cannot be ignored until, she forgives. This article looks at concept of dower in the Islamic Perspective and discusses its importance in marital life that forms an essential part of Muslim family law and it is practiced universally by all Muslims all over the World. It also examines several types of dower and focuses on the protection of woman's right to dower in Muslim Family Law. 


\section{Literature Review}

The issue of provision rights to women in Islamic law is debatable and discussed broadly all over the world. There are some misconceptions that Islam is not providing rights to woman. Muslim Countries all over the Muslim World enacted laws for the protection and promotion of women's status in the light of general principles of Islamic Law. Debates started all over the World that Islam is protecting woman's rights or not. A rich literature is available on woman's rights in Islamic Law, legislations of the countries nationally and internationally. All the countries all over the world including Muslim countries trying to promote and protect socio-legal status of women. United Nations has focused on the issue of provision rights to women in all spares of their lives including marital rights. The available literature on women's rights in Islam or woman human rights in National and International Law is; Internationally, UN Charter, UDHR and particularly CEDAW is providing the gender equality without any discrimination and protecting the rights of woman. All these UN documents are ratified by the Muslim countries including Islamic Republic of Pakistan. In Family matters, legislation has been enacted in the light of Islamic law and Pakistani statutory law is also providing marital rights to women. The role of Pakistani superior judiciary is remarkable in promotion and protection of women's rights particularly in family matters.

There is a bulk of literature on women's rights and some indications regarding rights of women in family matters. Firstly, general books, written on women's rights in Islam by several authors in different languages like Huquq Al-Nisa', Huquq Al-Mar'ah in Arabic, Aurtun key Huquq in Urdu and Women in Islam, Women's Rights in Islam and the status of woman in Islam, in English. Classical books like Al-Hidayah by Imam Al-Marghinani and Al-Mabsut by Imam Al-Sarakhi, Al Majmu" by Imam Al-Nawawi, Al-Mughni by Ibn Qudamah, Al-Umm by Imam Al-Shafi'i, Al-Muhalla by Imam IbnHazm and I 'lam Al-Muwaqqi in by Imam Ibn al-Qayyim. These books contain Islamic law as a whole which includes different aspects of women's rights. A book titled Tahrir Al-Mar'ah fi 'Asr Al-Risalah by 'Abdul Halim Abu Shaqqah is a main book in present era on Women's Rights. The author has added two other volumes five and six to expound the rights of women in the light of the Holy Quran and Sunnah of the Holy Prophet (PBUH).

Besides this, there are few books and articles relevant to women's rights but all these books and articles do not provide the clear picture of protection of women's rights in Islamic Law. The current paper is different from all work done by the scholars mentioned above and it focuses on woman's rights to dower guaranteed by Islamic Law. The details of available literature relevant to dower particularly and Muslim family law generally in the shape of books, articles, case law is to be discussed. Firstly, the books are: 
(Ali, 2000) discusses in her book different things relevant to women's rights. Firstly, she explains women human rights in Islam and compares with International Law. She actually focuses on gender equality and highlights the issues of gender discrimination such as testimony. She also presents the rights provided by the Constitution of Islamic Republic of Pakistan. With regard to my topic, she discusses Muslim Personal Law and its implications on women. In this part of the book, she starts with historical background of family law in Pakistan, and then discusses the issue of consent of guardian in marriage with reference to Saima Waheed case.

Shah (2006) begins with the introduction of Human Rights in Islam, the equality between men and women. He also explains the legal status of women in Pakistan and focuses on gender equality by referring the articles of the Constitution of Islamic Republic of Pakistan. He also elaborates the Human Rights of Women provided international documents such as CEDAW and focuses on gender discrimination. Fyzee (2008) is one of the Indian contemporary scholars, he introduces the Family Law of India and Pakistan. While discussing the topics, he also referred some case law regarding the marital issues such as dower and maintenance but not discussed in detail (Fyzee, 2008). Tanzil-urRahman (1978) discusses several topics of Muslim Personal Law one by one and presents the Islamic and Pakistani legal perspective as well. He also refers case law on the subject. (Tanzil-ur-Rahman, 1978). There are some relevant articles to the study, discussing the several marital rights of women.

Ranjha \& Cheema (2014) examine some judgments of the Supreme Court of Pakistan with regard to the protection of women's rights. This paper highlights the role of the Supreme Court in protecting rights of women within the framework of the Constitution of Islamic Republic of Pakistan (Cheema, 2014).

Martin Lau (1996) has examines the very famous case namely "Saima Waheed Case". The author discussed Saima Waheed case decided by the superior judiciary with regard to the consent of wali in marriage. In fact, this case was highlighted and promoted by the National and International media that's why, it was analyzed by several authors nationally and internationally (Lau, 1996). The same issue was discussed by Ali (1996) that a sui juris woman can get married without the consent of guardian (Ali, Is an Adult Muslim Women Sui Juris? , 1996). In this article she introduced the concept of marriage, types of marriage, the status of marriage in the context either civil contract or sacrament. In the end of this article, she discussed the consent of wali in marriage with focusing on Saima Wahed case (Ibid).

Ayesha Shahid (2010) in her article addressed the issue of post-divorce maintenance to woman in Islamic perspective and highlighted the practices and application of postdivorce maintenance in Muslim and Non-Muslim states. She also prescribed the law of Pakistan in this regard and she also checked the role of judiciary in provision of post- 
divorce maintenance. In the end she proposed that the divorced woman has to be provided reasonable maintenance so she can live with dignity (Shahid, 2010).

Prof. Dr. Muhammad Munir (2009) has focused on the judgments decided by the superior judiciary for the period of five years. The author analyzed briefly several cases decided by the superior judiciary on the topics of Family Law, such as capacity of an adult Muslim girl to marry without the consent of guardian, option of Puberty, custody of minor, Khul" divorce, maintenance of wives and children. In fact, he introduced the legislation in the area of family law in Pakistan and highlighted the role of superior judiciary in protecting and promoting women's marital rights (Munir, 2009).

\section{Research Methodology}

The research methodology of this paper includes an extensive reading of available literature either classical fiqhi or contemporary. It also observes women's rights all over the world, with special reference to protection and promotion of women's rights in Islamic and legal perspective. Library and other electronic resources are utilized for accomplishing the task. In this research paper, a qualitative and comparative research methods from classical Islamic Law and contemporary legal methods are used to complete various component of this research. To understand classical Islamic Law, textual methodology is used based on texts of the Holy Qur'an, Sunnah of the Holy Prophet (PBUH), and then classical Fiqhi books from all schools of thought. The jurisprudential opinions of Muslims Jurists based on methods of Usul al-Figh (Islamic Jurisprudence) are also important. Their explanation, elaboration and derivation of rulings from the holy Islamic texts have been done using the methods of the textual research as well. This research also involves reanalyzing, interpreting and reviewing the opinions of jurists. The research is based on primary and secondary sources of Islamic law, however, rational methodology is also applied to elaborate where it deemed necessary. Social sciences methods such as descriptive, comparative, analytical research methods have been used to understand the research where needed. Both primary and secondary sources are consulted for developing the argumentation of the issues. Original and proper texts of the Holy Qur'an and Traditions of the Holy Prophet Muhammad (PBUH) are not quoted due to the structure of the research journal; however, translations are quoted and elaborated where necessary. Moreover, translation of ayat of the Holy Qur'an, is taken by Abdullah Yusuf Ali. As for as translation of ahadith of the Holy Prophet $(\mathrm{PBUH})$, written by the researcher after consulting different translations and dictionaries.

\section{The Importance of Dower in Islam}

The importance of the dower in Shari 'ah arises from the fact that it fulfills a variety of functions that contribute to the success and prosperity of the marriage relationship. Firstly, 
giving a dower to a woman in marriage contract is a sign of respect, she feels more respectable and exercises the right to own in the same way men do. In Pre-Islamic era, a woman was treated as property that was owned. However, in Islam she is known as a dignified human. She acquired the right to use her money the way she desires. This has a positive impact on the future of the family as it strengthens the bond between a wife and her husband. Secondly, provision of dower is solely the right of wife that would lose its sanctity and authority if paid to anyone else as guardian. In the era of Jahiliyyah a woman's guardian, whether he is her father or somebody else, used to take the whole dower by giving her nothing. In this regard Abd al-'Ati states:

"Payment of the dower to the bride herself probably minimizes the element of self-interest and power of the guardian in his choice of husband for the ward. He became mainly concerned with what is best for the woman. This change, and many others, made by Islam tended to remove control over their affairs from the women's male relatives and protectors and to vest it in themselves" (Hummudah, 1977, p. 65).

Third important point with regard to the dower is that it also helps in bringing about the feeling of pleasure and happiness in woman, so she has more pride and self-confidence. She would be a good wife and marriage partner. Usually, she does not have any relationship with the husband before marriage. Thus, it is evident that a dower would guarantee that the relationship would proceed smoothly. Another consequence of the prescription of the dower is that giving a dower provides husband an opportunity to learn, bear responsibility and live up to this responsibility. If husband is not required to pay dower, he would look down on woman and he would probably even try to get rid of her because he did not invest any effort to get her. Imam Al-Kasani explains the point that:

"The dower was legislated and became an integral part of the marriage contract for the sake of marriage stability, because there might be lots of things in any marriage that may drive the husband to seek divorce. Had there not been a dower, it would have been much easier to obtain divorce even if the reason is very trivial or insignificant” (2000, p.485).

Finally, when a woman gets dower, she feels more secure and honored because the husband who can afford a dower and is willing to present it to a woman. It is automatically understood that a husband who can pay dower willingly, would be prepared to pay living expenses for her. Abdul 'Ati explains the point in this way: "It may be thought of as a manifest assurance on his part that the bride's economic security and rights will be maintained" (Hummudah, 1977, p. 46).

Imran Ahsan Khan Nyazee discusses that Mahr is an obligatory amount to be paid by the husband to the wife as an essential requirement of a valid marriage contract. It is an obligation that has to be paid before the marriage consummation but if delayed than it is 
considered a debt on husband that he has to pay his wife. According to Shari 'ah, it is a right (of a woman considers) in Islamic Law being an expression of the sanctity of the subject matter (Nyazee, 2012, p. 47). Provision of a dower to woman is one of the basic economic rights of a woman. No one can escape without providing it to a wife. In fact, offering a dower from husband and giving it to a wife indicates respect and honour for both to begin their marital life happily. These are some of the reasons that show how significant it is to impose a dower on men who want to get married.

\section{Legitimacy of Dower in Islamic Law}

The dower is something that is heavenly prescribed by Almighty Allah. It is legitimized from the Holy Qur' an and Sunnah of the Holy Prophet (PBUH).

\section{The Holy Quran}

The evidence for the legitimacy of dower comes from the Holy Quran as Almighty Allah states

"And give the women (on marriage) their dower as a free gift; but if they, of their own good pleasure, remit any part of it to you, Take it and enjoy it with right good cheer" (The Holy Quran, 4:4).

This verse explicitly states that women should be given their dowers, which implicitly constitutes a call to abandon the pre-Islamic practices pertaining to the dower and this is what the word "Atu" (give) in the previous verse implies, as it is used in the imperative form. Muslim Jurists (Ibn Kathir, 1999) interpreted this verse and expressed the view that the people who "give" are either the husbands or the guardians. In the case of the husbands, they are obliged to give women their dowers "Nihlatan", which means out of their own good pleasure. As for the guardians are concerned, they have to give the dowers that they receive on behalf of women, because it is forbidden for them to keep anything from these dowers unless they are allowed to do so by the women themselves. It is possible that a woman may give some of her dower to her husband or her guardian. However, a husband or a guardian is not permitted to deceit or to do anything that take the dower from woman, but if woman voluntarily gives something out of her dower either a guardian or husband.

It is a common practice in Muslim World that a husband has to pay a dower out of his own will, whereas the woman is not required to pay anything to the man for the marriage to proceed. Although marriage is a mutual contract between husband and wife. $\mathrm{He}$ is the man only who pays a dower, proposes to her and this costs him money. 
Another verse for the obligation of the dower is also mention in the Holy Quran as Almighty Allah says:

"Also prohibited are the women already bound in marriage, except the bondwomen you come to own. It has been written by Allah for you. All (women), except these, have been permitted for you to seek (to marry) through your wealth, binding yourself, (in marriage) and not only for lust. So, to those of them whose company you have enjoyed, give their dues (dower) as obligated. There is no sin on you in what you mutually agree upon after the (initial) agreement. Surely, Allah is All-Knowing, All-Wise" (The Holy Quran, 4: 24).

Imam A1-Qurtubi explains that this verse provides evidence for the existence of sadaq, or dower in any marriage contract. Thus, all marriage contracts must include dower (AlQurtubi, 1964, p. 127).

\section{The Sunnah of the Holy Prophet (PBUH):}

The Sunnah of the Holy Prophet is used to explain what had been revealed in the Holy Quran regarding a woman's right to her dower. The evidence is also found in the Ahadith of the Holy Prophet (PBUH) as Ibn Abbas narrated that:

"When Hazrat Ali (RA) got married to Hazrat Fatima (RA), the Holy Prophet (PBUH) said to him. Give her something as a (dower). Hazrat Ali (RA) replied: I have nothing with me. The Prophet asked: Where is your Hutaimiyyah Shield? I said: It is with me. He said: Give it to her" (SunanAl-Nasa'i, Book: 26, Kitab Al-Nikah, Hadith: 180).

This Hadith indicates that Hazrat Ali (RA) should give her something though it may be of a little value. He has to give her something that is symbolic such as a shield. The purpose of doing this is to make her happy.

There is another Hadith narrated by Hazrat Abu Salama (RA) that:

"I asked Hazrat Aisha (RA): How much (amount) had Allah's Messenger (PBUH) given as dower to his wives? She replied: His (dower) to his wives was twelve 'uqiyyas and one nash. She asked, Do you know what a nash was? I replied: No. She said: it was half an "uqiyyas; so the total was five hundred dirhams and that was the Holy Prophet's dower to his wives" (Sunan Ibn Majah, Book:9, KitabAlNikah, Hadith: 1960).

These are only few of the many Ahadith s of the Holy Prophet (PBUH) that strongly support and explain the dower. The Messenger of Allah (PBUH) set a good example and 
gave his wives their full dowers. He paid each of his wives five hundred dirhams for their dower. Furthermore, there was a consensus among Muslim jurists regarding the women's rights to their dowers, as they all agreed that there should be a dower in a marriage contract. They also elaborated that those who failed to fulfill the requirement of dower by tricking or cheating the woman would be strictly punished on the Day of Judgment. This is clearly prescribed in a Hadith of the Holy Prophet (PBUH) as said: "He who gets married to a woman and intends not to give her dower, and then he dies before she gets what she deserves, will face Allah on the day of Judgment as a fornicator" (Al-Tabarant, 1983, p. 40). This is a severe punishment from Almighty Allah to a husband who tries to get married to a woman but evades giving her anything of her dower through deceptive means.

\section{Validity of Marriage without Fixation of Dower}

The four Muslim schools of thought; Hanafi (A1-Sarakhsi, 1987, p. 403), Shafi' $i$ (AlShafi'i, 1987, p. 238), Maliki (Anas, 1994, p. 1164) and Hanbali(Ibn Qudamah, 1968, p. 48), opine that there is possibility the exact value of the dower is not fixed in a contract of marriage and there will be no effect on the validity of marriage tie. However, the Hanafi Jurists, in this case, said that if the amount of dower is not fixed then a woman would have (Mahr Mithl), a dower that is equal to dowers of women like her, no more no less, whether he had consummated the marriage with her or not. They argue that the dower is an obligation according to Islamic Law, how is it possible to get married to a woman without offering her a dower? This question has been answered by Imam Badruddin Al'Ayni(Al-'Ayni, 1990, p. 131), who said that the dower is an obligation in accordance with the Islamic legislation and it is an obligation not only for the sake of the marriage itself but also for the woman's honour. So there is no need to mention how much it is if it is only for the sake of marriage. Moreover, other three schools of thought (Maliki, Shafi' $i$, Hanbali), they express the view that it is preferable to fix the value of the dower in the marriage contract because this may save both the husband and the wife a lot of trouble in the future. There is an evidence that supports the legitimacy of marriage contract if the value of the dower is not fixed as Almighty Allah stated in the Holy Quran:

"There is no blame on you if ye divorce women before consummation or the fixation of their dower; but bestow on them (a suitable gift), the wealthy according to his means, and the poor according to his means; a gift of a reasonable amount is due from those who wish to do the right thing" (The Holy Quran, 2:236).

This Ayah comes with evidence that there is no sin or blame in divorcing the woman whose dower had not been fixed. This is so because divorce usually occurs after proper marriage or consummation. It implies that there had been a marriage although a dower 
was not specified. It concludes from this that marriage contracts that do not specify dowers are legitimate.

There are some ahadith supporting the point discussed above as narrated by Abdullah Ibn Mas'ud that:

"Once asked about a man who got married to a woman without naming a dower for her and he had never had a sexual relationship with her until he died. Ibn Mas'ud said that she deserved the same dower that women similar to her would usually get, no less and no more. She has to observe the iddah, which is a prescribed period of time during which a widow or a divorcee may not remarry, but she is entitled to inherit. Then, Ma'qal Bin Sinan said that this ruling is in accordance with what the Messenger of Allah (PBUH) had already ruled in a similar situation regarding a woman named Birwa' bint Washiq" (SunanAbiDawud, Book: 12, Kitab Al-Nikah, Hadith: 69).

There is another Hadith in the same meaning and context, narrated by 'Uqba Bin 'Amir (RA) that the Holy Prophet (PBUH) once said to a man:

"I declare you get married to so and so. The man said: I agree. The Holy Prophet (PBUH) then said to the woman: Do you accept so and so as a husband? The woman replied: Yes, I do. Thus, the two were married and there was no dower. When the man was dying, he said: the Prophet made me get married to so and so. I did not state a specific dower for her and, in effect, I gave her nothing. But, as a dower I gave her the arrow I used in Khaybar Battle. She took it and sold it for one hundred thousand dirhams" (SunanAbiDawud, Book: 12, Kitab AlNikah, Hadith: 72).

The previous verses of the Holy Quran and traditions of the Holy Prophet (PBUH) mentioned above, show that it is permitted to have a marriage contract even without specifying and fixing the dower. The woman is entitled to ask for her dower. The reason for permitting a marriage contract without dower is that the man did not deny the dower and did not ask her to drop it and did not agree with her on not paying it. On the contrary, they all agree that she deserves a dower but it happens sometimes that specifying the dower is delayed till after marriage and Islamic law providing relaxations to men as well, when feasible for him give the dower but don't forget it is a right of a woman protecting by law and couldn't be lifted even after death. But it has no effect on marriage contract that is valid without any doubt as discussed above according to Hanafi, Shafi'i, and Hanbali jurists. However Maliki jurists differentiated between 
the marriage was consummated or not. If the marriage had not been a consummated, then marriage contract would be invalid. If it had been consummated, on then woman was entitled to a dower similar to dowers of other women and she has the right to ask for Mahr Mithl and get it.

\section{Quantum of Dower}

All the Muslim Jurists have agreed that there are no restrictions on the maximum amount of a dower given to a woman. There is no explicit statement referring to the value of the dower neither in the Holy Quran nor in the Holy Sunnah of the Holy Prophet (PBUH). Therefore, it is up to the husband, how much dower he can afford. He is free to pay a high dower or low due to poverty or any other reasons. He is not forced to pay or give a high dower. In fact, it is left to the individuals to estimate what dowers to grant or get? It may vary from one person to another according to different factors such as customs, habits and traditions. Thus, the specification or fixation of the amount of the dower is not significant. An important thing in Islamic law is that the dower must contain some value, such as money and property. In some cases, it may have only a symbolic value. But, it should not be something that is forbidden by Almighty Allah. If the husband and the wife agreed on prohibited thing as a dower like wine, then the dower becomes invalid although the marriage contract itself remains valid. In this case, the wife gets a dower that is similar to dowers of other women like her in the family, in accordance with the teachings of Shari'ah.

\section{Maximum Amount of Dower}

The Majority of the Muslim jurists agreed that there should be no maximum limit of the dower. A man, who is going to get married, may pay as much as he can and as much he can afford it. The evidence of non-fixation of the dower is mentioned in the following verse of the Holy Quran, where it is stated:

"But if ye decide to take one wife in place of another, even if ye had given the latter a whole treasure for dower take not the least bit of it back: would ye take it by slander and a manifest wrong?" (The Holy Quran, 4:20).

Imam IbnKathir (1999) explains different interpretation of the word "qintar" as interpreted by the jurists, having concern with the verse. Al-Dahak said that a qintar means a lot of money. Some said it could be one thousand dinar s and some believed that a qintar is one thousand and two hundred dinars. Other estimations were given, such as twelve thousand, forty thousand, sixty thousand, seventy thousand, eighty thousand 
dinars, etc. Abu Hurairah (RA) reported that the Prophet had said that a qintaris "twelve uqiyyahs and the worth of each uqiyyah is more than what is between the sky and the earth" (IbnKathir, 1999, p. 359).

According to the Quranic verse, there is no specified maximum amount of dower which is to be paid to wife that is conditioned over financial stability of husband. There are also some examples from the Islamic history that support that there is no limit or fixation of dower. For example, 'Umar Ibn Al-Khattab offered forty thousand dinars as a dower for Umm-e-Kulthum, a daughter of Ali Ibn Abi Talib. Although he was reported to have asked people not to exaggerate in offering dowers, he later refrained from asking people not to have high dowers after he heard the verse mentioned above.

\section{Minimum Amount of Dower}

As discussed above that the all the jurists agreed that there is no maximum limit of dower. However, they have different opinions regarding, what might be an acceptable minimum limit of dower.

There are three different views on this matter. First, according to the Hanafi Jurists, the dower that the wife receives should not be less than ten dirhams. By supporting their opinion, they bring a Hadith of the Holy Prophet (PBUH) as said:"No dower for less than ten dirhams" (Sunan Al-Dar Qutani, Kitab Al-Nikah, Bab: Al-Mahr, Hadith: 11).

They also support this view on the basis of analogy. They say that there is a similarity here between the amount of money that makes a dower and that which may be counted as a theft, given that a thief's hand might be chopped off if the value of what he had stolen exceeds ten dirhams. They believe that this analogy provides more support for their viewpoint regarding the ten dirhams being a bottom line for a dower. Thus, according to them, a woman's marriage may not be consummated unless she had been paid a dower of at least ten dirhams. There is also another Hadith of the Holy Prophet (PBUH) in which he says: "Give something as a dower even if it is a ring made from iron" (Sahih AlBukhari, Book: 67, Kitab Al-Nikah, Hadith: 25).

In this Hadith the Holy Prophet (PBUH) is addressing a man who wanted to get married but had nothing to give as a dower. One might argue that an iron ring is worth much less than ten dirhams. This seems to contradict what has been said before. But the explanation of this is, it may be an exception in a general rule but there must be something presented as dower for the dignity and respect of a woman and it may not less than ten dirham. 
Maliki jurists said that the amount of a dower cannot be less than one quarter of a dinar worth of gold or three dirhams of pure silver. Imam Malik bin Anas says:

"I do not think anyone should get married with a dower of less than quarter of a dinar." (Anas, 1994, p. 152)

Therefore, according to Maliki Jurists, a man cannot get married to a woman with a dower of less than this and if he marries her and pays a dower of less than three dirhams, he will be required to pay the rest of the dower. However, if there is marriage but no conjugal relationship, he will be asked to complete paying the dower and if he does not the marriage contract will not be valid.

The third opinion is of Shafi' $i$ and Hanbali Jurists (Al-Shirazi, 1976, p. 55) regarding the minimum amount of a dower. They agree that there is no limit as to what the lowest dower might be. They believe that anything of value in terms of money, or that, which can be used to buy things, might be taken as a dower. They also refer a Hadith of the Holy Prophet (PBUH), in which he says:

"Do you have anything that you can present to her as a dower? The man replied: No. The Prophet said: Find something for her, even an iron ring will do" (Sahih Muslim, Book: 16, Kitab AlNikah, Hadith: 89).

Another Hadith supporting this view is narrated by 'Abdullah Ibn 'Amir IbnRabi'ah from his father as said:

"A woman from the Fazarah tribe got married for a dower of a pair of shoes. The Holy Prophet (PBUH) asked her: Are you fully satisfied with a pair of shoes as a dower? She replied: Yes. So the Holy Prophet (PBUH) permitted her to get a pair of shoes as dower and the marriage contract is considered valid" (Sunan Al-Timadhi, Book: 11, Kitab AlNikah, Hadith: 34).

From all this discussion, one has to say that it is a kind of obligation that people do not exaggerate when asking for dowers. Guardians, whether fathers or somebody else, should not ask potential husbands to pay very high dowers which they cannot afford because this will negatively affect the marriage prospects and perhaps be as tumbling block. Although the Shari'ah did not specify the value of a dower, as we have discussed above; it is in accordance with the Sunnah of the Holy Prophet (PBUH) that people adhere to dowers that are convenient to all parties, both husbands and wives. People should give up showing off and exaggerating in dowers because this may lead only to misery and more problems in the future. Hazrat Aisha (RA) narrated that the Holy Prophet (PBUH) said: "The most blessed women are those that take the least dower" (Nayl al-Awtar, Kitab Al- 
Sadaq, Hadith: 4). It was also reported that once Hazrat Umar Ibn Al-Khattab (RA), while preaching, said:

"Do not exaggerate in women's dowers, because if high dowers were ever honourable in our worldly life or would lead to piety in the afterlife, the Prophet would have done this himself. He had never offered a dower for any of his wives nor had any of his daughters asked for a dower that exceeds twelve ounces" (Sunan Al-Tirmadhi, Book: 11, Kitab Al-Nikah, Hadith: 36).

In this regard, IbnTaymiyyah says:

"It is disliked but not forbidden for a man to offer a dower that he cannot pay in cash nor can be repaid if it is a debt" (Ibn Taymiyyah, 1991, p. 192).

In this context it can be concluded that although the Islamic Law did not specify any limits, maximum or minimum for dower, yet it is recommended that people should be resilient in determining the dower quantum instead of status ostentation. This would enable the poor to manage ceremonial expenses of marriage within their financial resources.

It also kept in mind that the practices of Mahr Fatimi and Shar' $i$ Mahr are not having any source and legal authority. In some villages of Pakistan, the amount of Fatimi Mahr is almost thirty two rupees and twenty eighty for Shar ' $i$ Mhar respectively. But the fact is that the amount of Dower for Hazrat Fatima (RA) was more than 27 tola of silver and dower amount of wives of the Holy Prophet (PBUH) was more than 27 tola silver except Hazrat Umm -e- Salmah (RA); her amount of dower was almost ten dirham (Kandhalvi, 1974, pp. 70-71).

\section{Prompt and Deferred Dower}

Generally, Dowers are paid before the contract of marriage as indicated by the sayings of the Holy Prophet (PBUH) and the stories of the Prophet's companions. All the Muslim jurists have been agreed upon this issue and found no differences among them. Imam Ibn Taymiyyah states that:

It is more appropriate that the dower be paid before the husband consummates with his wife if possible. It is permitted that the husband prepays the dower or he may delay it. He further states that "In the past, forefathers who set good examples for us, used to prepay the full dower before consummation and they usually would not delay paying anything of it (Ibn Taymiyyah, 1991, p. 195). 
It is preferred to pay the dower before marriage or at the time of Nikah to a woman or her guardian, however, it could also be delayed, Islamic law also permitted the delay of paying dower because usually people are overburdened with the ceremonial expenses and the delay would ease the wedding.

When a man wants to delay the dower, he has to approach the woman or her guardian and ask for the possibility of delaying the dower. The dower may be fully delayed or partially. It happens sometimes that the woman herself want to postpone getting the dower. Because she wants to have a small prepaid dower which a man can afford and she asks for a higher deferred dower which she gets if the husband dies or if he divorces her. This would help the woman in the future after the husband had left. No matter what are the reasons for deferring the dower, it is still legitimate according to Islamic Law. However, Muslim jurists disagreed on the conditions according to which it is possible to postpone paying the dower. Hanafi jurists (Al-Kasani, 2000, p. 515) said that it is lawful to delay the dower, provided that it does not refer to or contain any outrageous ignorant remarks, such as saying to the wife "I will marry you for a thousand dinar s payable when my financial circumstances get better or when the wind blows." Because such conditions are imprecise, uncertain and unclear, contract cannot be concluded on the basis of ambiguous and vague conditions. Consequently, postponing the dower in such cases is invalid according to them. Islamic law does not make any contract valid that includes gharar (uncertainty). Maliki Jurists (A1-Dasuqi, n.d, p. 297) explained that the issue of postponing the dower depends on what type of dower we have at hand. If the dower is available locally, such as residence, clothes, or animals, then it cannot be postponed and the wife is supposed to get it immediately. Deferring the payment of the dower in this case is prohibited even if the wife accepted the delay. However, if the dower is not available in the country then it is possible to delay paying the dower for a definite period of time. Otherwise, the marriage contract will be invalid.

The Shafi'i and Hanbali Jurists (Al-Sharbini, 1985, p. 222; IbnQudamah, 1968, p. 261) permitted the delay in paying the dower, partially or fully, whether it is available in the country or not regardless of whether it is money or otherwise as long as the delay is for a definite period. I think the opinion of Shafi'i and Hanbali Jurists understand the issue here, because it makes marriage requirements and procedure much easier for those planning to get married. If one cannot prepay a dower, this dower will be a debt that he has to repay at a specific time.

Prompt Dower preferably is to be paid at the time of a marriage contract or it could be payable on demand of a woman. Deferred dower also be demanded by the wife if the time is not specified for its payment. Pakistani superior judiciary is playing its role in this regard as directed to pay the deferred dower on the wife's demand particularly when he contracted another marriage (Muhammad Azam vs. ADJ, PLJ 2006 Lah. 927). 


\section{Conclusions}

Dower is the first right that woman receives through her husband very after her marriage. It is obligatory for husband to execute this right that is solely given to his wife; however, she can forgive it fully or partially. Husband cannot oblige her for the eradication of dower. It is an honour for a wife that displays inclination of a husband to his wife. In Islamic Law, dower is mandatory condition to be fulfilled at the time of marriage contract or as mutually agreed. The present study has argued that her financial dependency over her husband is a right bestowed by Islam. It also ponders over the opinions of Muslim Jurists with their justifications for conditioning dower. Islamic law does not specify the minimum or maximum amount of dower. The dower as a right aims to facilitate and honour woman; however, the sagacity behind the unspecified amount is left upon the individuals. They are free to decide the quantum according to their financial strength. Islam promotes simplicity and modesty therefore spiritual essence of dower should not be waved off by flamboyance. Islam also strengthens woman's right to dower by granting her authority to deny from marital rights with husband in case of non-payment of dower. None the less, she can also end the marriage tie in some cases for non-provision of dower amount. In a nutshell, it can be said that Islam is the only religion that protects woman's right to dower and granting her full ownership to utilize the dower amount according to her wills and desires.

\section{References}

Al-Qur'an

A1-Dasuqi, M. (n.d). Hashiath Al-Dasuqi (Vol. 2). Beirut: Dar Al-Fikr.

A1-Sarakhsi. (1987). Al-Mabsot (Vol. 5). Beirut: Dar Al-Ma'rifah.

Abdul Kadir vs. Salima, 08 (Allahbad 1886).

Ahmadi, A. A.-N. (1992). Manhaj al-Sunnah fi al-Zawaj. Cairo: Dar Al-Salam.

Al- Tabarant, S. (1983). Al-Mu jam al-Kabir (Vol. 8). Cairo: Maktabah Ibn Taimiyyah.

Al-'Ayni, B. u. (1990). Al-Binayah fi Sharh al-Hidayah (Vol. 5). Beirut: Dar Al-Fikr.

Al-Bayhaqi, A. I.-H. (2003). Al-Sunan Al-Kubra. Beirut: Dar Al-Kutub Al-Ilmiyyah.

Al-Bukhari, M. I. (1987). Sahih Al-Bukhari. Beirut: Dar Ibn Kathir. 
Al-Kasani, I. (2000). Bada'i Al-Sana'i (Vol. 5). Beirut: Dar Al-Marifah.

Ali, S. S. (1996). Is an Adult Muslim Women Sui Juris? Yearbook of Islamic and Middle Eastern Law, pp.156-174.

Ali, S. S. (2000). Gender and Human Rights in Islam and International Law: Equal before Allah, Unequal before Man. The Hague: Kluwer Law International.

Al-Nasai, A. A. (1986). Sunan Al-Nasai. Halb: Maktab Al-Matbuat Al-Islamiyyah.

Al-Qurtubi, M. I. (1964). Al-Jami`li-Ahkam al-Qur’an (Vol. 05). (A. A.-B. Atfish, Ed.) Qahirah: Dar Al-Kutub Al Misriyyah.

Al-Qushayri, M. I. (n.d). Sahih Muslim. Beirut: Dar Ihya' Al-Turath Al-Arabi.

Al-Rahman, D. T. (n.d). Majmoah Qawanin Islam. Islamabad: Islamic Research Institute.

Al-Shafi‘, M. (1987). Al-Umm (Vol. 5). Beirut: Dar Al-Ma'rifah.

Al-Sharbini, M. (1985). Mughni Al-Muhtaj (Vol. 3). Cairo: Matba‘ al-Mustafa Al-Babi.

Al-Shawkani, M. I. (1993). Nayl Al-Awtar Sharh Muntaqa Al-Akhbar. Egypt: Dar AlHadith.

Al-Shirazi, I. (1976). Al-Muhadhab fi Fiqh al-Imam Al-Shafi 'i (Vol. 2). Cairo: Matba'ah Mustafa Al-Babi.

Al-Tirmadhi, M. I. (1975). Sunan Al-Tirmadhi. Egypt: Matbah Mustafa Al-Babi.

Al-Zuhayli, W. (1985). Al-Fiqh Al-Islami Wa Adillatuhu. Damuscus: Dar Al-Fikr.

Anas, M. B. (1994). Al-Mudawwanah (Vol. 2). Beirut: Dar Al- Kutub Al-Ilmiyyah.

Ash'ath, A. D. (n.d). Sunan Abi Dawud. Beirut: Al-Maktabah Al-Asriyyah.

Baillie, N. B. (n.d). Digest of Muhummadan Law. Lahore: Premier Book House.

Cheema., Z. U. (2014). Protection of Legal Status of Women in Pakistan: An Analysis of The Role of Supreme Court, . IJPSS, Volume 4, Issue 4. 
Fyzee, A. A. (2008). Outlines of Muhammadan Law. New Delhi: India: Oxford University Press.

Hanbal, A. I. (1998). Al-Musnad. Beirut: Alim Al-Kutub.

Hummudah, A. (1977). The Family Structure in Islam. Indiana: American Trust Publications.

Ibn Kathir, I. (1999). Tafsir al-Qur’an al-‘Azim. Beirut: Mu’assasah Al-Rayyan.

Ibn Qudamah, A. I. (1968). AI-Mughni (Vol. 7). Qahirah: Maktabah Al-Qahirah.

Ibn Taymiyyah, A. (1991). Majmuat al- Fatawa (Vol. 32). Riyadh: Dar al-'Alim AlKutub.

Kandhalvi, M. A. (1974). Ma'alim Al-Qur'an (Vol. 5). Idarah Ta'limat al-Qur'an.

Lau, M. (1996). Pakistan: Abdul Waheed vs. Asma Jehangir (the Saima Waheed Case). Yearbook of Islamic and Middle Eastern Law, pp.518-531.

Majah, A. A. (n.d). Sunan Ibn Majah. Beirut: Dar Ihya' Al-Kutb Al-Arabiyyah.

Muhammad Azam vs. ADJ, PLJ 2006 Lah. 927.

Munir, P. D. (2009). The Rights of Women and the Role of Superior Judiciary in Pakistan with Special Reference to Family Law Cases from 2004-2008 . Pakistan Journal of Islamic Research.

Mustafa, I. (n.d). Al-Mu ‘jam Al-Wasit. Istanbul: Al-Maktabah Al-Islamiyyah.

Nyazee, I. A. (2012). Outlines of Muslim Personal Law. Rawalpindi: Federal Law House.

Qutani, A. I.-D. (2011). Sunan Al-Dar Qutani. Beirut: Dar Ibn Hazm.

Shah, N. A. (2006). Women, the Koran and International Human Rights Law. Leiden/ Boston: The Netherland : Martinus Nijhoff Publishers.

Shahid, A. (2010). For the sake of Justice: Protecting Divorced Women's Rights in Pakistan by Re-examining the Shari'ah Principles of Mutat (Post Divorce Maintenance). JISPL. 
Siddiqi, M. I. (1988). The Family Laws of Islam. Delhi: International Islamic Publishers.

Tanzil-ur-Rahman, D. (1978). A Code of Muslim Personal Law. Karachi: Hamdard Academy.

Zahrah, A. (1981). Al-Ahwal Al-Shakhsiyyah. Qahirah: Dar Al-Fikr Al-Arabi.

Dr. Hafiz Muhammad Siddique is an Assistant Professor at Faculty of Shariah \& Law, International Islamic University, Islamabad, Pakistan.

Dr. Muhammad Atif Aslam Rao is an Assistant Professor in the Department of Islamic Learning, University of Karachi. 